\title{
Geologic position of the Younger Dryas subfossil forest in the Warta River valley, central Poland
}

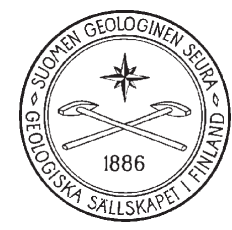

\author{
Danuta Dzieduszynska and Joanna Petera-Zganiacz \\ Department of Quaternary Studies, Institute of Earth Science, \\ University of Lodz, Narutowicza str., 88, 90-139 Lodz, Poland
}

\begin{abstract}
Numerous tree trunks are present in the Late Weichselian deposits on the low terrace of the Warta river valley, in central Poland. This study concerns the well preserved tree remnants as well as accompanying depositional series and their sedimentary environments in relation to the geological position. The depositional sequence presented covers periods from the Middle Weichselian onwards. The riparian forest dates at the Younger Dryas. Environmental changes connected with rapid cooling were responsible for its destruction.
\end{abstract}

Keywords (GeoRef Thesaurus, AGI): sediments, organic sediments, trees, subfossils, paleoenvironment, climate change, Weichselian, Younger Dryas, Kozmin, Poland

Corresponding author email: dadziedu@geo.uni.lodz.pl

Editorial handling: Pertti Sarala

\section{Introduction}

Since 1995, geological and palaeogeographical investigations of the Quaternary deposits in the open pit area of the Miocene lignite exploitation within the ADAMÓW JSC Lignite Mine have been carried out at the Department of Quaternary Studies of University of Lodz. The area is situated in the lowland part of central Poland (coordinates $\mathrm{N}$ $52^{\circ} 04^{\prime} 51^{\prime \prime}$ and E 18\%40'3") (Fig. 1). Geomorphologically, the mine area lies on the low terrace on the western side of the Warta river valley (Fig. 2). It is located in the middle section of the river course, where the river flows northward. The valley signifi- cantly expands there, attaining up to $8-10 \mathrm{~km}$ in width, while its morphological elements, e.g. terraces, are hardly distinguishable.

The extensive exposures connected with the mining activity gave an opportunity to investigate the whole Quaternary complex. Results obtained provided the basis for stratigraphical and palaeogeographical investigations (Klatkowa, 1996; Forysiak et al., 1999; Turkowska et al., 2000, 2004; Petera, 2002; Petera \& Forysiak, 2004; Forysiak, 2005; Petera-Zganiacz, 2007). In 2007, the main interest was focused on the remnants of forest within the 


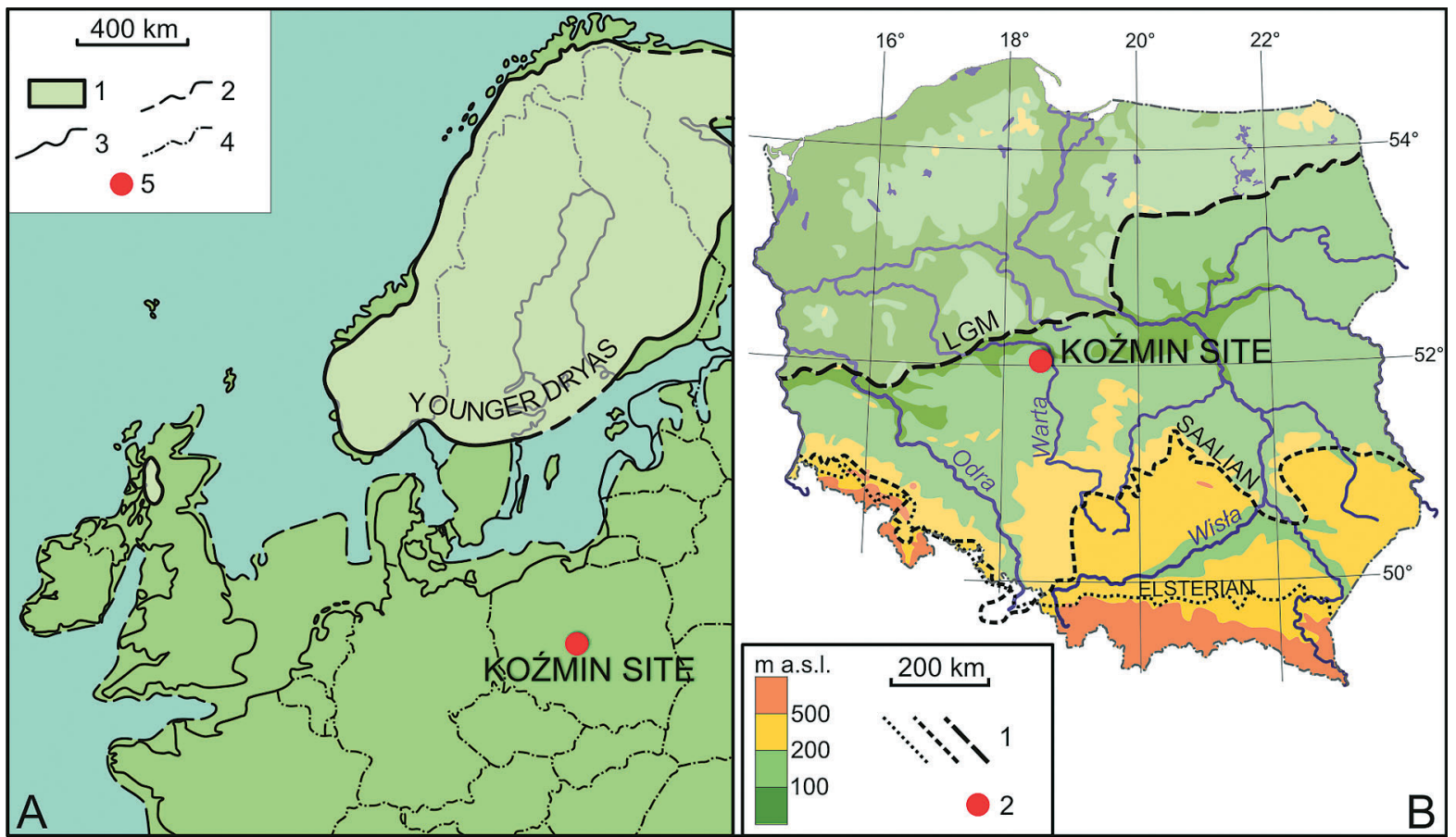

Fig. 1. Location of the investigated site in relation to the Younger Dryas ice-sheet extent in Europe (A) and in relation to the Pleistocene glaciations in Poland (B). Symbols in A: 1 = ice-sheet (after Forsström \& Punkari, 1997); 2 = coastline in the Younger Dryas; 3 = present coastline; 4 = borders of countries; 5 = location of the investigated site. Symbols in B: 1 = extents of the ice-sheets (after Marks, 2005); 2 = location of the investigated site.

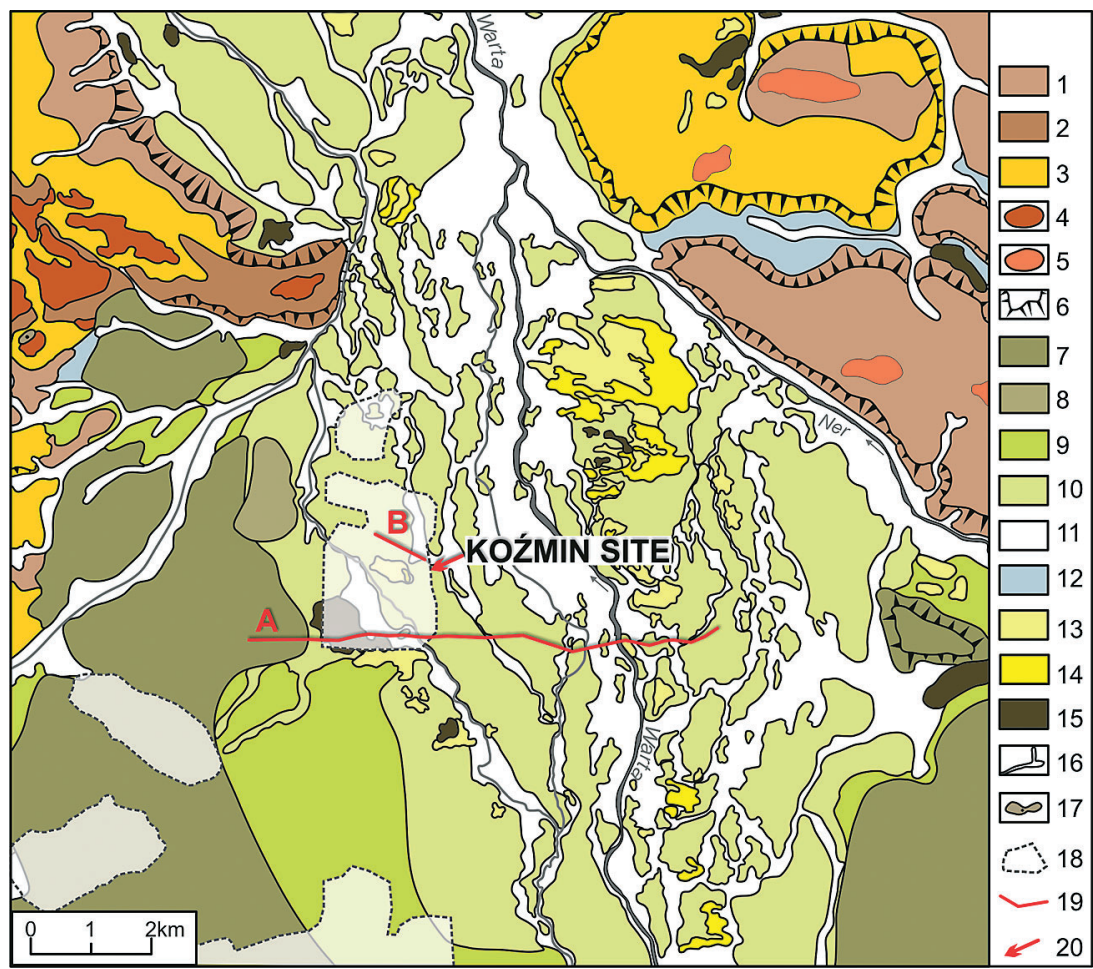

Fig. 2. Geomorphological map of the study area (after Forysiak, 2005 modified). 1 = morainic plain, 2 = hummocky morainic plain, 3 = fluvioglacial plain, $4=$ end-morainic hillocks, $5=$ kames, $6=$ slopes, $7=$ lower terrace of Warsaw-Berlin ice-marginal streamway, $8=$ erosional terrace $9=$ alluvial high terrace, $10=$ alluvial low terrace, 11 = valley floor, 12 = lacustrine plain, $13=$ aeolian plain, $14=$ dunes, 15 = peatlands, $16=$ valleys of various origin, 17 = closed depressions, 18 = postexploitation areas and outcrops of the Adamów Lignite Mine, 19 = location of the geological crosssections (cf. Fig. 7); 20 = location of the investigated site. 
organic material at the Kozmin site. An organicrich unit has been found sandwiched between the units of a fluvial origin (Fig. 3). At the beginning of the studies of the horizon of the subfossil trees, they were surveyed in the walls of the lignite mine excavation (Fig. 4) (Petera-Zganiacz \& Dzieduszynska, 2007).

The purpose of the present study is an analysis of the remnants of subfossil forest at the Kozmin site, especially in relation to the organic-rich unit and to the overlying and underlying mineral deposits. As the tree trunk horizon, as well as the most material in which it is rooted, belongs to Late Weichselian climatic deterioration of the Younger Dryas, the authors point to the probability of permafrost reactivation and other palaeogeographical factors registered in the sedimentary environment of the distinguished units.

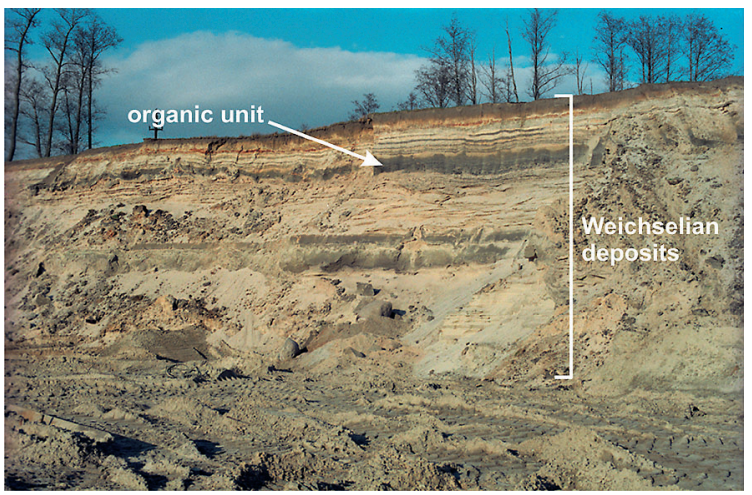

Fig. 3. Position of the organic-rich unit within Weichselian deposits (photo by H. Klatkowa, 1996).

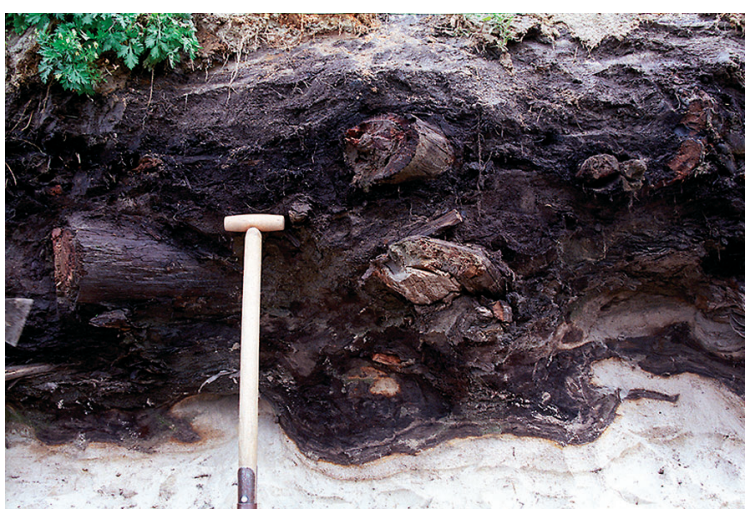

Fig. 4. The organic-rich unit with tree trunks (photo by J. Petera-Zganiacz, 2007).

\section{Methods}

A detailed fundamental field study has been undertaken in 2011 in the open test pit of about $160 \mathrm{~m}^{2}$. For the exact registration of the trees position and the sampling purposes, an archaeological approach was used; successive layers of deposits have been removed and cleaned. Altogether the forest remnants have been documented in 7 levels every 5 to $7 \mathrm{~cm}$ (Figs. 5, 6). The orientation and dimensions of each tree trunk and stump have been measured.

The studies of the mineral material comprised sedimentological analyses according to Miall (1978) modified by Zielinski (1998), grain-size composition complemented with Folk \& Ward (1957) coefficients and quartz-grain abrasion analysis in the fraction of 0.63-0.8 mm, using Cailleux (1942) method as modified by Klatkowa (1991) and Manikowska (1993).

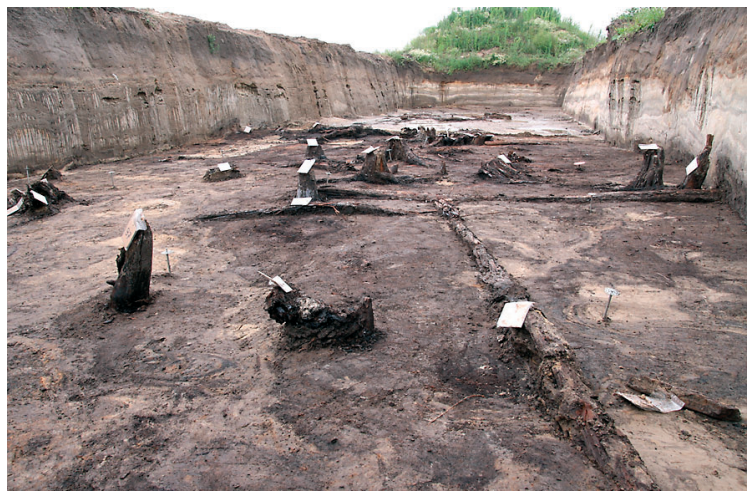

Fig. 5. Stumps and collapsed trunks visible in the open test pit (level S3) (photo by J. Petera-Zganiacz, 2011).

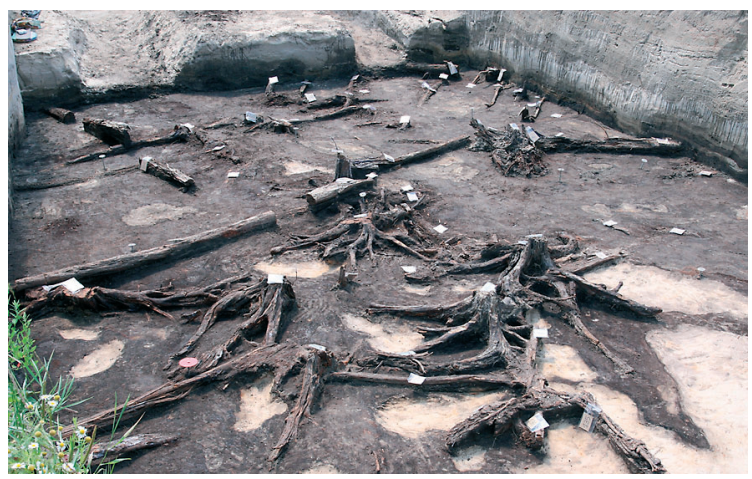

Fig. 6. Stumps rooted in the organic-rich unit, with well preserved root systems and collapsed trunks (level S4) (photo by J. Petera-Zganiacz, 2011). 
The chronostratigraphy of the site was determined based on radiocarbon dating of the samples of the organic material and tree trunks (Petera-Zganiacz, 2007; Dzieduszynska et al., 2011), thermoluminescence (TL) and optically stimulated luminescence (OSL) dating of samples taken from the underlying sandy sediments (Petera-Zganiacz \& Adamiec, 2010) and results of preliminary pollen analyses (Turkowska et al., 2000, 2004; Petera, 2002). The conventional age determination was calibrated according to INTCAL09 (Reimer et al., 2009).

\section{Geology and relief of the area}

The area under investigation lies in the WestEuropean Variscian Plate, within the Szczecin - Lodz - Miechów Basin of a Cretaceous age. In the middle part of the basin, developed the Konin Elevation with several tectonic grabens (Widera, 1998). The Kozmin site is located in the southern part of the elevation, within the Adamów Graben. Stankowski $\&$ Nita (2004) and Petera-Zganiacz et al. (2010) claim that neotectonics were probably still active during the Pleistocene. The grabens are filled with Palaeogene and Neogene deposits, including the Miocene series containing lignite.

As the area was covered by ice sheets several times during the Quaternary, the Quaternary sequence is predominated by sediments of glaciogenic origin, with fluvial sediments as a considerable component. Among the deposits are till beds being laid down during the successive glaciations, glaciofluvial and glaciolacustrine series as well as fluvial gravels, sands and silt (Fig. 7A). Despite the subsidence tendency within the graben and conditions facilitating preservation of the deposit, hiatuses due to erosion by the pra-Warta River are common. Thickness of the deposits within the graben area ranges from about 30 up to $60 \mathrm{~m}$, while outside it decreases, even to less than $10 \mathrm{~m}$.

The last ice cover was present in the study area during the Saalian Stage glaciations (Odranian Glaciation in Polish stratigraphy after Lindner,
2005). The Weichselian Cold Stage was an ice-free period (Fig. 1B). The closest position of the ice sheet front of about $20 \mathrm{~km}$ to the north took place during the Last Glacial Maximum (LGM). Therefore, during the whole Weichselian, the environment of the study area experienced a range of phenomena under periglacial conditions. The uppermost part of the Quaternary sedimentary complex is related to the Weichselian fluvial activity (Figs 3, 7B), mostly of Middle Weichselian ones and also the Late Weichselian events.

With reference to the Younger Dryas, the study area was at the distance of about $800 \mathrm{~km}$ from the ice sheet southern extension in Scandinavia (Fig. 1A). Global climatic changes registered for that time are in central Poland distinctly expressed and left an imprint in the particular sedimentary systems and the landscape (Dzieduszynska, 2011).

The Warta River valley, in the Kozmin area, is incised into a morainic plateau and a fluvioglacial plain intermingled with morainic hillocks and kames (Fig. 2). These landforms are built from till and fluvioglacial gravels and sands of the Saalian glaciations. The major valley elements are remnants of erosional terraces of the Warsaw-Berlin icemarginal streamway of Saalian age and two alluvial terraces from the Weichselian. The Middle Weichselian high terrace is composed of sand and sand with silt. In the Kozmin area, it is not morphologically manifested. The larger part of the valley is occupied by the low terrace of the Late Weichselian age. The vertical profile of deposits of that terrace is organic-rich mud at the base, usually followed by fine sand and sand with silt. As a rule the terrace is cut by numerous channels developed in three generations, from the Younger Dryas onwards (Forysiak, 2005). The system of those channels, nowadays dry, provide evidence of a multichannel style of the Warta River before regulation. The valley floor is built of organic silt, silt and sand; it continues along the Warta River, its small tributaries and the dry channels. The low terrace, especially on the east side of the valley, is covered with Late Weichselian and Holocene dunes. The relief of the present-day valley is dominated by several anthropogenic forms of the post-exploitation areas. 
A
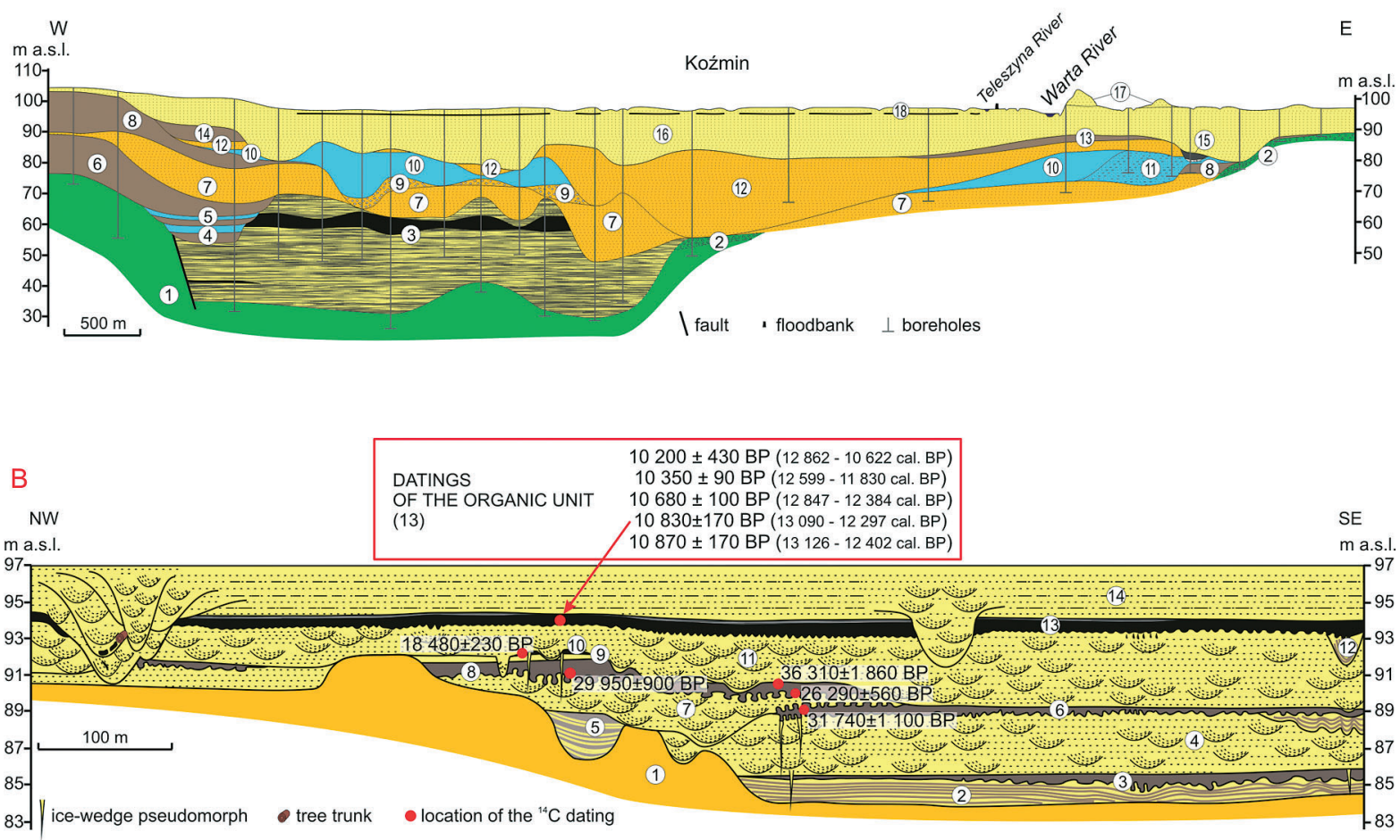

Fig. 7. Interpreted drawings of cross-sections indicated in Fig. 2. Symbols in A: Cretaceous, $1=$ marl, $2=$ weathered marl; Neogene, 3 = clay, silt, sand and lignite; Quaternary, Elsterian, 4 = the oldest till and glaciolacustrine silt, $5=$ older till and glaciolacustrine silt, 6 = younger till; Saalian, 7 = fluvial sand and gravels, $8=$ lower till, $9=$ lower fluvioglacial sand and gravels, 10 = glaciolacustrine silt and fine sand, 11 = glaciolacustrine sand and sand with silt, 12 = upper fluvioglacial sand and gravels, 13 = upper till, 14 = glacial loamy sand; Eemian, 15 = organic-rich silt; Weichselian and Holocene, 16 = fluvial sand, sand and gravel, and sand with silt, $17=$ aeolian sand, $18=$ organic-rich unit. Symbols in B (modified from Petera, 2002): Saalian, 1 = fluvioglacial sand and gravels; Early Weichselian, 2 = sand and organic-rich silt, $3=$ organicrich silt; Middle Weichselian, $4=$ sand, $5=$ organic-rich silt and sand, $6=$ lower organic-rich silt, $7=$ sand, $8=$ upper organic-rich silt; Late Weichselian, 9 = silty sand, 10 = peat, 11 = sand, 12 = sand and organic-rich silt, $13=$ organic-rich mud and peat, 14 = sand and silty sand.

\section{Previous studies}

Previous studies at the Kozmin site were focused on stratigraphy, sedimentology and palaeogeography of the Weichselian, especially on the periods of Middle Weichselian and LGM (Forysiak et al., 1999; Petera, 2002; Petera \& Forysiak 2003). Besides, the investigations concentrated on evolution of the multichannel system of the Warta River in the Late Weichselian and Holocene (Turkowska et al., 2000; 2004; Petera \& Forysiak, 2004; Forysiak 2005). From the Kozmin area, several series of a fluvial origin separated by organic ones were reported. The uppermost organic horizon (in which the subfossil forest was later discovered) was analyzed in order to estimate an age of neighbouring mineral series using radiocarbon dating and pollen method.

The results of pollen analysis indicated an open pine forest with a slight admixture of Betula, but generally vegetation was predominated by herbaceous plants. Later on, pine forest was replaced by open birch forest with patches of heliophilous plants. Finally, pollen spectrum contains single grains of rush plants and aquatic species, thus the top of the profile reflects stand waters or a pool with very limited discharge. Therefore the organic unit must have been formed under cold climatic conditions, progressively more severe towards the top of the unit. Detailed interpretation of the results of the pollen analysis at Kozmin with comments by a palynologist 
has been presented earlier (Turkowska et al., 2000, 2004).

The results of radiocarbon dating of the organic material (Fig. 7) cover an age range between $10870 \pm 170{ }^{14} \mathrm{C} \mathrm{BP}(\operatorname{Lod} 699)$ or 13 126-12 402 cal. BP (95.4\%), and $10200 \pm 430{ }^{14} \mathrm{C} \mathrm{BP}$ (Gd 9740) or $12941-10660 \mathrm{cal}$. BP (95.4\%) (Dzieduszynska et al., 2011). Therefore, its origin has been estimated to be of Alleröd and early Younger Dryas age, thus in general to the period between 13150 and $11550 \mathrm{cal}$. BP corresponding to the turn of the Greenland Interstadial 1 (GI - 1cl $1 \mathrm{~b})$ and the cold Greenland Stadial 1 (GS - 1), according to the scheme proposed by the INTIMATE (INTegration of Ice-core, MArine and TErrestrial records) group (Björck et al., 1998).

\section{Lithological characteristics and sedimentary environ- ments of the units}

\subsection{Lower unit}

The Middle Weichselian unit consists of sand deposits (Fig. 3, 7B), locally with fine gravels at the base. The sediment is mostly composed of mediumgrained sands, well or moderately sorted (Fig. 8B). Through cross-bedding, planar cross-stratification, horizontal and ripple lamination of the unit point to deposition as channel facies of a sand-bed braided river (Zielinski, 1998). The sediment completely lacks organic matter. One of the most important features registered there is a high content of wind-abraded grains (RM) up to 50-60\%, while a content of grains shaped up in a fluvial environment (EL) decreases to less than $10 \%$ (Fig. 8C), which is characteristic for the early Late Weichselian extraglacial alluvia (Gozdzik, 1980, 2007; Van Huissteden et al., 1986; Klatkowa, 1991; Manikowska, 1993; Kasse et al., 1995). Thus, the unit represents a sand-bed braided river environment under cold climatic conditions of the LGM period.

The topmost part of the unit consists of sandy or sandy-silty series OSL-dated at $13900 \pm 64$ BP (GdTL-925) (Petera-Zganiacz \& Adamiec, 2010). Hence, the unit formed after the coldest period of the Weichselian. There are no sharp boundaries and sedimentary structures, such as ripple stratification and horizontal lamination, suggesting a decrease in flow energy (Fig. 8A).

\subsection{Middle unit}

The organic unit is usually composed of organic mud, and, at places of peat. Its thickness varies between a few and $50 \mathrm{~cm}$ (Fig. 3, 7B). Based on a macroscopic observation, there is no evidence of any flow during deposition in the lower part of the unit. The structure of the deposit is massive. In the upper part of the unit, appear lenticular, wavy and flaser bedding which indicate deposition interrupted by a slight flow (Fig. 9). The organic unit is occasionally covered by gyttja, especially where the base of mud or peat occurs deeper. The gyttja deposit presumably points to an uplift of the ground water table and the formation of small pools. The organic unit is distinguished by deformation features observed at the bottom of the unit, such as flat-bottomed
A

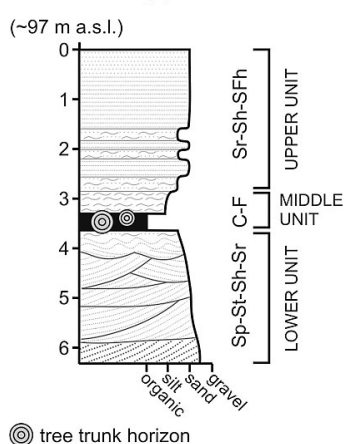

B

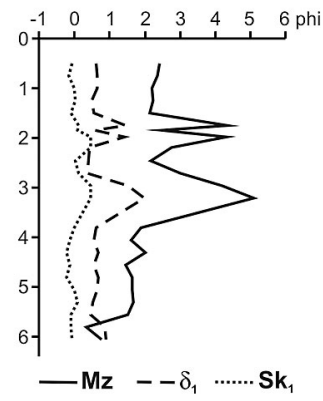

C

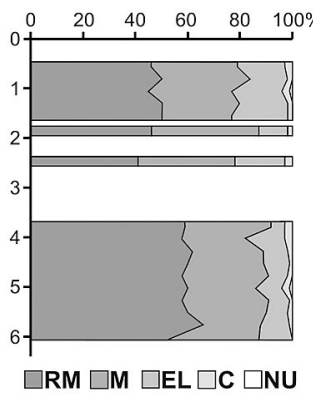

Fig. 8. Structural and textural properties of the sediment units. (A) Lithofacial profile and code (after Miall, 1978 and Zielinski, 1998). (B) Grain-size coefficients (after Folk \& Ward, 1957): $\mathrm{Mz}=$ mean grain size, $\delta_{1}=$ standard deviation, Sk = skewness. (C) Quartz-grains abrasion (after Cailleux, 1942; Klatkowa, 1991; Manikowska, 1993): RM = round mat, $\mathrm{M}=$ intermediate, $\mathrm{EL}=$ shiny, $\mathrm{C}=$ crushed, $\mathrm{NU}=$ unabraded (fresh). 


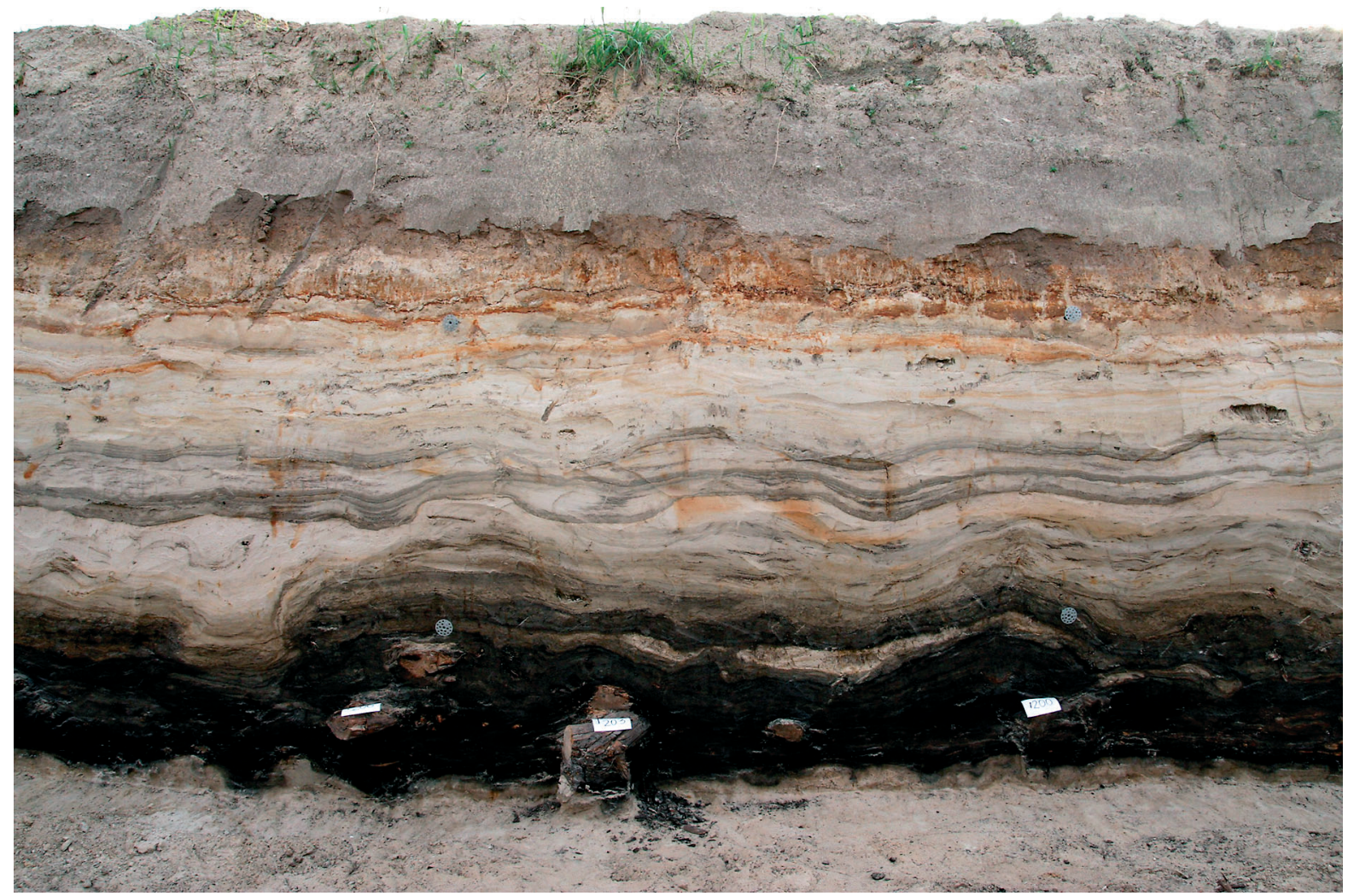

Fig. 9. The organic unit with tree remnants covered by the sandy and sandy-silty unit (photo by J. Petera-Zganiacz, 2011).

involutions and drop structures (Fig. 10). Their base as a rule attains a certain depth within the underlying sandy series where structures have sunk. No change in lithology has been observed.

The time frame for the formation of the organic unit has been determined using conventional radiometric method and pollen analysis (see chapter "Previous studies"). In general, the palaeobotanical signal is in agreement with the radiocarbon datings and confirms that deposition of the organic unit took place during the Alleröd decline and the beginning of Younger Dryas.

\subsection{Upper unit}

The organic mud series is covered by $2-3 \mathrm{~m}$ thick sandy and sandy-silty deposits probably of Younger Dryas, constructing the present-day surface (Fig. 3, $7 \mathrm{~B}, 9)$. The lowermost part of this unit is usually composed of a $20-50 \mathrm{~cm}$ thick sand layer with horizontal bedding or ripple stratification prevailing.

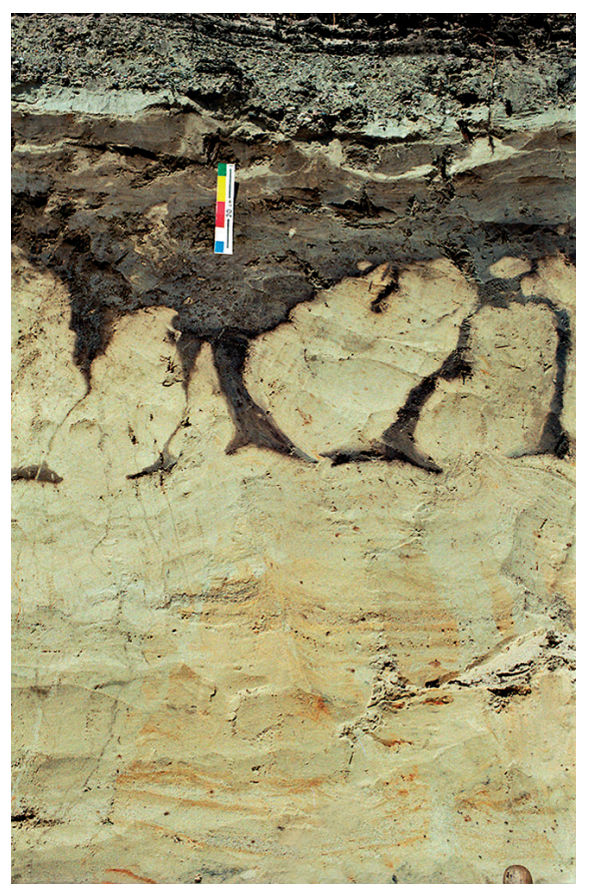

Fig. 10. Flat bottomed structures in the base of the organic-rich unit (photo by H. Klatkowa, 1996). 
Above, dominates sandy-silty material with horizontal or flaser bedding as the most common sedimentary structures (Fig. 8A). The unit is believed to represent overbank facies of an anabranching river type 2 (Nanson \& Knighton, 1996). At places, the channels of this anabranching river cut the organic mud unit (Fig. 7B). Those channels, which may have developed during the Younger Dryas are as a rule filled with trough cross-bedded moderately or well sorted medium-grained sand (Fig. 8B) (Turkowska et al., 2000, 2004; Forysiak, 2005). Quartzgrain analysis (Fig. 8C) indicates a content of windabraded grains (RM) almost as high as in deposits of the top part of the upper unit; the value of about $50 \%$ is not surprising for the Younger Dryas period as it is a time of intense aeolian activity (Gozdzik, 1995, 2007; Kasse, 1995; Klatkowa, 1996). Interestingly, also the percentage of grains characteristic of fluvial environment (EL) increases almost twice up to even $20 \%$. Such growing content of EL grains should be interpreted as their supply from other sedimentary environments resulted from river erosion (Woronko, 2001).

\section{Tree trunk horizon}

The tree remnants are associated with the three above described units: primarily with the organicrich mud unit and partly with the top of the underlying sandy unit and the base of the covering series (Fig. 3, 7B). The stumps have been documented in situ as collapsed trunks as well as individual branches and roots. The well preserved forest remnants reveal clearly visible annual tree rings. According to preliminary assessment the investigated tree stand was dominated by a pine (Pinus) forest with birch (Betula) and probably juniper (Juniperus).

In the lower sand unit, the wood occurs sparsely, in every case at its top, usually as collapsed trunks and stumps. The distinguishing feature of the trunks is that their thickness is bigger than trunks found in the other units. One of the pine trunks was radiocarbon dated at $11850 \pm 80{ }^{14} \mathrm{C} \mathrm{BP}(\mathrm{MKL}$ $256)$ or $13874-13454$ cal. BP (95.4\%) (Dzieduszynska et al., 2011). The stumps of the unit have been tilted, but there is no sign of their transportation. Since they are tilted in the same direction, a wind action may be considered as responsible for the destruction.

Organic unit contains a fundamental part of the tree remnants: the stumps and collapsed trunks, as well as individual branches. Most stumps are found in situ (Fig. 5). They are rooted in the organic unit, with well-preserved root systems (Fig. 6). The stumps are spaced 1 to about $3 \mathrm{~m}$ apart in the test pit. Between the braided roots, assemblages of cones have been found. The collapsed trunks reach up to a few metres in length. Their diameters are locally more than $0.2 \mathrm{~m}$. As their diameters equal or exceed the mud thickness, it is difficult to state the real position of the trunks in relation to the base or top of the unit. In some localities, a significant assemblage of trunks was documented, where they were found lying one on the other even in three levels which causes the increasing thickness of the unit (Fig. 4). Additionally, the trunks are somewhat flattened, by pressure from overlying material. For some collapsed trunks, interlocking roots have been registered, which may testify that they were not relocated. Most wood remnants are coated with bark. One of the collapsed pine trunk gave the date of $10310 \pm 90{ }^{14} \mathrm{C} \mathrm{BP}$ (Lod 1402) or $12156-$ 11761 cal. BP (95.4\%) (Dzieduszynska et al., 2011).

The tree remnants of the uppermost unit are represented by collapsed trunks and pieces of branches but the unit is devoid of stumps. The collapsed trunks are generally stripped of bark and are situated within the base that is the sandy section of the unit. That section is built up of coarser material, indicating relatively high energy conditions on the floodplain. Such a position and preservation of the wood suggest that the trees may have been washed away, transported by a flood in high energy environment and then quickly buried in the overbank sediment.

\section{Discussion and concluding remarks}

The stratigraphic position of the particular units and the tree trunk horizon sets the main problems 
discussed in the article within the time of dynamic climatic changes of the termination of the last glacial period, with special reference to the Younger Dryas cold spell. Based on the Greenland oxygen signal (i.e. Johnsen et al., 2001) as well as sedimentological and palaeobiological data from annually laminated sediments of the German lakes (Litt et al., 2003) and the Gosciaz Lake in central Poland (RalskaJasiewiczowa et al., 1998) the shift from the temperate Alleröd conditions to the Younger Dryas cooling occurred in a few decades. The climate stimulations indicate that Younger Dryas winter temperatures decreased down to -20 to $-25^{\circ} \mathrm{C}$, while summer temperatures decreased to $10-14^{\circ} \mathrm{C}$ for the area of northwestern and central Europe (Isarin et al., 1998).

Conditions in central Poland during the Late Weichselian were sufficient to forest development. Vegetation associations of the optimal part of Alleröd were in central Poland dominated by dense pinebirch forest, while during the Younger Dryas cooling they were replaced by forest-tundra-steppe communities (Madeyska, 1998). Especially favourable for the forest existence during deteriorating climatic conditions are terrains of river valleys. The Kozmin site in the Warta River valley is one such area where also both geological and geomorphological records appeared conductive to palaeoenvironmental studies.

The morphological element which is worth to be emphasized for the site presented is the extensive alluvial plain left by an extraglacial sandy braided river of the LGM. Afterwards, this surface became a floodplain covered by forest. At the turn of Alleröd and Younger Dryas, the groundwater level was raised, which resulted in the deposition of organic material. Properties of the organic series, such as an assemblage of valuable nutrients, enabled the existence of a forest ecosystem irrespective of the Younger Dryas climatic deterioration.

The outstanding features of the investigated site is well preserved wood, due to geological properties like a silt admixture at the top of the organic unit and the environmental processes, in example a quick covering of the floodplain with overbank deposits of an anabranching river. During the Holocene, the lower terrace became morphologically separated and nowadays stands 1-2 $\mathrm{m}$ above the valley floor. Such a morphological position has resulted in the high groundwater level and water saturation of the tree trunk horizon throughout 12000 years. The availability of the trunks for the present study is facilitated owing to the mine drainage works.

Among the factors mentioned above as possible reason of the forest destruction are either strong wind or high-energy floods. Apart from these catastrophic events, the authors have also taken into consideration at least local permafrost reactivation beneath the organic unit with the onset of the Younger Dryas climatic deterioration. Water-logging of the ecosystem possibly leading to the decay of trees is supported by the gyttja formation and the flatbottomed structures at the base of the organic unit. The distinct boundary, to which the reported involutions reach, may presumably have coincided with a permafrost table which acted as a solid base to which the organic deposit could sink.

The matter of permafrost conditions during the Younger Dryas is widely discussed. According to the most common opinion, in Poland, similar to the north-western European territory, final permafrost retreat took place during the Alleröd. Researchers dealing with the problem vary in opinions on its reactivation as a response to the Younger Dryas conditions, mainly because of the lack of clear evidence for the formation of ice wedge casts as an unambiguous proof of permafrost conditions (i.e. Böse, 1995; Gozdzik, 1995; Klatkowa, 1996). Since cryoturbations are attributed to loading due to density difference, their occurrence does not confirm a permafrost reactivation (i.e. Kasse, 1999), nevertheless their cryogenic origin is possible (Vandenberghe, 1988; Swanson et al., 1999).

Similar finding of a subfossil forest of Younger Dryas age is known from the lignite area of Cottbus in eastern Germany (Spurk et al., 1999). Trees from that German site enabled to extent the pine chronology and the tree-ring based ${ }^{14} \mathrm{C}$ calibration to up to $12323 \mathrm{BP}$, thus to the middle Younger Dryas (Friedrich et al., 1999, 2004). The Kozmin site seems to be more promising because of the accompanying organic horizon which is an impor- 
tant archive of palaeoenvironmental information and offers an opportunity to carry out high resolution geological, geochronological and palaeoecological analyses, and to obtain detailed climatic proxies of the last termination time with special reference to the time of the Younger Dryas dramatic climate deterioration. The studies are in progress.

\section{Acknowledgements}

The research is financially supported by a grant from the $\mathrm{Na}$ tional Science Centre, No N N306 788240 "Palaeogeographical conditions of existence and destruction of the Late Weichselian forest in the Warta River Valley (the Kolo Basin)". The authors thank reviewers for the comments, which greatly improved the text.

\section{References}

Björck, S., Walker, M., Cwynar, L., Johnsen, S., Knudsen, K.L., Lowe, J., Wohlfarth, B. \& INTIMATE Members 1998. An event stratigraphy for the last Termination in the North Atlantic region based on the Greenland ice-core record: a proposal by the INTIMATE group. Journal of Quaternary Science 13, 283-292.

Böse, M. 1995. Problems of dead ice and ground ice in the central part of the North European Plain. Quaternary International 28, 123-125.

Cailleux, A. 1942. Les actions éoliennes périglaciares en Europe. Les Mémoires de la Société Géologique de France 46, 1-176. (in French)

Dzieduszynska, D. 2011. Ochlodzenie mlodszego dryasu i jego efekty morfogenetyczne w regionie lódzkim (Younger Dryas cooling and its morphogenetic importance in the Lodz Region, central Poland). Acta Geographica Lodziensia 97. (in Polish)

Dzieduszynska, D., Petera-Zganiacz, J. \& Krapiec, M. 2011. The age of the subfossil trunk horizon in deposits of the Warta River valley (central Poland) based on ${ }^{14} \mathrm{C}$ datings. Geochronometria 38, 334-340.

Folk, R.L. \& Ward, W.C. 1957. Brazos River bar: a study in the significance of grain size parameters. Journal of Sedimentary Petrology 27, 3-26.

Forysiak, J. 2005. Ewolucja doliny Warty miedzy ujsciem Widawki a ujsciem Neru (The development of the Warta River Valley between Burzenin and Dobrów in the late Quaternary period). Acta Geographica Lodziensia 90, 1116. (in Polish)

Forysiak, J., Miotk-Szpiganowicz, G. \& Petera, J. 1999. Geologic setting and palynologic examination of the Vistulian sediments at Kozmin near Turek, Central Poland. Geological Quaterly 43, 85-98.

Forsström, L. \& Punkari, M. 1997. Initiation of the Last Gla- ciation in Northern Europe. Quaternary Science Reviews 16, 1197-1215.

Friedrich, M., Kromer, B., Spurk, M., Hofmann, J. \& Kaiser, K.F. 1999. Paleo-environment and radiocarbon calibration as derived from Lateglacial / Early Holocene tree-ring chronologies. Quaternary International 61, 27-39.

Friedrich, M., Remmele, S., Kromer, B., Hofmanjn, J., Spurk, M., Kaiser, K.F., Orcel, C. \& Küppers M. 2004. The 12,460-year Hohenheim oak and pine tree-ring chronology from Central Europe - a unique annual record for radiocarbon calibration and paleoenvironmental reconstructions. Radiocarbon 46, 1111-1122.

Gozdzik, J.S. 1980. Zastosowanie morfoskopii i graniformametrii do badan osadów w Kopalni Wegla Brunatnego „Belchatów”. Studia Regionalne 4 (9), 101-114. (in Polish)

Gozdzik, J.S. 1995. A permafrost evolution and its impact on some depositional conditions between 20 and $10 \mathrm{ka}$ in Poland. Biuletyn Peryglacjalny 34, 53-72.

Gozdzik, J.S. 2007. The Vistulian aeolian succession in central Poland. Sedimentary Geology 193, 211-220.

Isarin, R.F.B., Renssen, H. \& Vandenberghe, J. 1998. The impact of the North Atlantic Ocean on the Younger Dryas climate in northwestern and central Europe. Journal of Quaternary Science 13, 447-453.

Johnsen, S., Dahl-Jensen, D., Gundestrup, N., Steffensen, J.P., Clausen, H.B., Miller, H., Masson-Delmotte, V., Sveinbjornsdottir, A.E. \& White, J. 2001. Oxygen isotope and palaeotemperature records from six Greenland ice-core stations: Camp Century, Dye-3, GRIP, GISP2, Renland and NorthGRIP. Journal of Quaternary Science 16, 299307.

Kasse, C. 1995. Younger Dryas climatic changes and aeolian depositional environments. In: Troelstra, S.R., van Hinte, J.E. \& Ganssen, G.M. (eds.) The Younger Dryas. Koninklijke Nederlandse Akademie van Wetenschappen Verhandelingen, Afd. Natuurkunde, Erste Reeks, deel 44, 27-31.

Kasse, C. 1999. Can involutions be used as palaeotemperature indicators? Biuletyn Peryglacjalny 38, 95-110.

Kasse, C., Vandenberghe, J. \& Bohncke, S.J.P. 1995. Climatic change and fluvial dynamics of the Maas during the late Weichselian and early Holocene. Palaoklimaforschung/ Palaeoclimate Research 14, 123-150.

Klatkowa, H. 1991. Remarks on dating and chronostratigraphy of Late Vistulian and Holocene aeolian episodes in Middle Poland. Zeitschrift für Geomorphologie, NF, Supplement-Band 90, 77-88.

Klatkowa, H. 1996. Symptoms of the permafrost presence in Middle Poland during the last 150000 years. Biuletyn Peryglacjalny 35, 45-86.

Lindner, L. 2005. Nowe spojrzenie na liczbe, wiek i zasiegi zlodowacen srodkowopolskich w poludniowej czesci srodkowo-wschodniej Polski (A new look at the number, age and extent of the Middle Polish Glaciations in the sout- 
hern part of central-eastern Poland). Przeglad Geologiczny 53, 145-150. (In Polish)

Litt, T., Schmincke, H.-U. \& Kromer, B. 2003. Environmental response to climatic and volcanic events in central Europe during the Weichselian Lateglacial. Quaternary Science Reviews 22, 7-32.

Madeyska, T. 1998. Zróznicowanie roslinnosci Polski u schylku ostatniego zlodowacenia (Vegetation in Poland at the close of the last glaciation). Studia Geologica Polonica 113, 137-180. (In Polish)

Manikowska, B. 1993. Mineralogy and abrasion of sand grains due to Vistulian (Late Pleistocene) aeolian processes in Central Poland. Geologie en Mijnbouw 72, 167-177.

Marks, L. 2005. Pleistocene glacial limits in the territory of Poland. Przeglad Geologiczny 53, 988-993.

Miall, A.D. (ed.) 1978. Fluvial Sedimentology. Canadian Society of Petrolium Geologists Memoir 5, 1-859.

Nanson, G.C. \& Knighton, A.D. 1996. Anabranching rivers: their cause, character and classification. Earth Surface Processes and Landforms 21, 217-239.

Petera, J. 2002. Vistulianskie osady dolinne w basenie uniejowskim i ich wymowa paleogeograficzna (Vistulian valley deposits in the Uniejów Basin and their palaeogeographical significance). Acta Geographica Lodziensia 83, 1-174. (In Polish)

Petera-Zganiacz, J. 2007. Osady rzeki plenivistulianskiej w Kozminie (Deposits of the Plenivistulian river at the Kozmin site). Acta Geographica Lodziensia 93, 43-56. (In Polish)

Petera-Zganiacz, J. \& Adamiec, G. 2010. The age of the Warta river valley deposits based on ${ }^{14} \mathrm{C}$, TL, OSL dating methods (Kotlina Kolska, Middle Poland). $10^{\text {th }}$ International Conference "Methods of Absolute Chronology". Gliwice, 22-25.04.2010, pp. 112.

Petera-Zganiacz, J. \& Dzieduszynska, D. 2007. Wymowa paleogeograficzna horyzontu pni kopalnych w osadach póznego vistulianu (Palaeogeographical significance of subfossil tree trunks in the Late Vistulian sediments). Acta Geographica Lodziensia 93, 57-66. (In Polish)

Petera, J. \& Forysiak, J. 2003. The Last ice sheet extent in Central Poland. Geological Quaterly 47, 574-578.

Petera, J. \& Forysiak, J. 2004. Holocenska ewolucja systemu wielokorytowego Warty w okolicach Kozmina (Holocene evolution of the multichannel Warta system near Kozmin). Acta Geographica Lodziensia 88, 27-40. (In Polish)

Petera-Zganiacz, J., Czubla, P., Gruszka, B., Forysiak, J., MiotkSzpiganowicz, G., Olszak, I. \& Pawlowski, D. 2010. The Kozmin glacial lake - its origin, age, deposits and palaeoecology. $12^{\text {th }}$ Annual Conference of the INQUA PeriBaltic Working Group "Ice, water, humans - Quaternary landscape evolution in the PeriBaltic region", Greifswald, 13-17.09.2010, pp. 141-142.

Ralska-Jasiewiczowa, M., Goslar, T., Madeyska, T. \& Starkel, L. 1998. Lake Gosciaz, central Poland. A monographic study. Part 1. W. Szafer Institute of Botany, Polish Academy of Science, Kraków, 1-340.

Reimer, P.J., Baillie, M.G.L., Bard, E., Bayliss, A., Blackwell, P.G., Bronk Ramsey, C., Buck, C.E., Burr, G.S., Edwards, R.L., Freidrich, M., Grootes, P.M., Guilderson, T.P., Hajdas, I., Heaton, T.J., Hogg, A.G., Hughen, K.A., Kaiser, K.F., Kromer, B., McCormac, G., Manning, S., Reimer, R.W., Richards, D.A., Southon, J.R., Talamo, S., Turney, C.M.S., van der Plicht, J. \& Weyhenmeyer C.E. 2009. Intcal09 and Marine 09 radiocarbon age calibration curves, 0-50 000 years cal BP. Radiocarbon 51, 1111-1150.

Spurk, M., Kromer, B. \& Peschke, P. 1999. Dendrochronologische, palynologische und Radiokarbon-Untersuchungen eines Waldes aus der Jüngeren Tundrenzeit. Quartär 49/ 50, 34-38. (In German)

Stankowski, W. \& Nita, M. 2004. Stratigraphy of Late Quaternary deposits and their neotectonic record in the Konin area, Central Poland. Geological Quaterly 48, 23-34.

Swanson, D., Ping, C.-L. \& Michaelson, G.J. 1999. Diapirism in soils due to thaw of ice-rich material near the permafrost table. Permafrost and Periglacial Processes 10, 349-367.

Turkowska, K., Forysiak, J., Petera, J. \& Miotk-Szpiganowicz, G. 2000. Morfogeneza powierzchni Kotliny Kolskiej w okolicach Kozmina (Morphogenesis of the Kolo Basin near Kozmin). Acta Geographica Lodziensia 78, 98-134. (In Polish)

Turkowska, K., Forysiak, J., Petera, J. \& Miotk-Szpiganowicz, G. 2004. A Warta River system during the Younger Dryas in the Kolo Basin (Middle Poland). Quaestiones Geographicae 23, 83-107.

Vandenberghe, J. 1988. Cryoturbations. In: Clark, M.J. (ed.) Advances in Periglacial Geomorphology. Wiley, Chichester, pp. 179-198.

Van Huissteden, J., Vandenberghe, J. \& Van Geel, B. 1986. Late Pleistocene stratigraphy and fluvial history of the Dinkel Basin (Twente, eastern Netherlands). Eiszeitalter und Gegenwart 36, 43-59.

Widera, M. 1998. Ewolucja paleomorfologiczna i paleotektoniczna elewacji koninskiej (Palaeomorphological and palaeotectonical evolution of the Konin Elevation). Geologos 3, 55-103. (In Polish)

Woronko, B. 2001. Znaczenie analizy obtoczenia i zmatowienia powierzchni ziarn kwarcowych frakcji piaszczystej w interpretacji genetycznej osadów czwartorzedowych. In: Mycielska-Dowgiallo, E. (ed.) Eolizacja osadów jako wskaznik stratygraficzny czwartorzedu. Warszawa, pp. 3338. (In Polish)

Zielinski, T. 1998. Litofacjalna identyfikacja osadów rzecznych (Lithofacial identification of alluvial sediments). In: Mycielska-Dowgiallo, E. (ed.), Struktury sedymentacyjne i postsedymentacyjne w osadach czwartorzedowych i ich wartosc interpretacyjna. Warszawa, pp. 195-257. (In Polish) 